\title{
Histoproteomic Characterization of Localized Cutaneous Amyloidosis in X-Linked Reticulate Pigmentary Disorder
}

\author{
Vincenzo L'Imperio ${ }^{a}$ Irene Bruno ${ }^{c}$ Ingrid Rabach ${ }^{d}$ Andrew Smith $^{b}$ Clizia Chinello $^{b}$ \\ Martina Stella ${ }^{b}$ Fulvio Magni ${ }^{b}$ Fabio Pagni ${ }^{a}$ \\ ${ }^{a}$ Department of Surgery and Translational Medicine, Pathology, San Gerardo Hospital, and bepartment of \\ Medicine and Surgery, Proteomics and Metabolomics Unit, University of Milano-Bicocca, Monza, and \\ 'Department of Pediatric Clinic, and ${ }^{\mathrm{d} I n s t i t u t e}$ for Maternal and Child Health, IRCCS Garofalo Burlo, University of \\ Trieste, Trieste, Italy
}

Dear Editor,

Skin involvement is an inconsistent but characteristic feature of the X-linked reticulate pigmentary disorder (XLRPD; OMIM 301220), a rare entity that is characterized by recurrent infections and autoimmune reactions against various organs with respiratory, gastrointestinal, and neurological manifestations [1]. Given that many patients require transplantation [2], dermatologists should consider graft versus host disease (GVHD) during a differential diagnosis. In XLRPD, histology essentially reveals the presence of amyloid deposits that are mainly localized within the dermoepidermal junction of adult patients, leading to the hypothesis that this is an age-related condition [3-5]. In their report, Pezzani et al. [2] described a case of genetically confirmed XLRPD in which no dermopathological symptoms were present at diagnosis. However, during 4 years of follow-up, the same child developed a peculiar skin lesion that was clinically suggestive of GVHD (Fig. 1a, b). A skin biopsy showed a prominent amyloid deposition, whilst also being Congo red positive (Fig. 1c, d), anti-AAP negative (concentra- tion $0.4 \mathrm{mg} / \mathrm{mL}$, dilution 1:300; Altas Antibodies, AlbaNova University Center, Stockholm, Sweden), light chain negative (DAKO, Glostrup, Denmark) with intense immunoreactivity of the amorphous deposits for IgG (DAKO, Glostrup, Denmark), and CK AE1/AE3 positive (concentration $0.4 \mathrm{mg} / \mathrm{mL}$, dilution 1:300; Altas Antibodies; Fig. 1e, f). Further proteomic analysis detected the overexpression of a group of proteins that were potentially involved in the pathogenesis of the localized cutaneous amyloidosis (LCA; Table 1) [69]. In particular, one of these proteins was identified as apolipoprotein E, a chaperon protein found in the dermis of patients affected by lichen amyloidosis and macular amyloidosis, thus suggesting that a dysregulation of the apoptosis system is an initial cause of the disorder [8]. Another candidate from the same group of proteins is galectin-7, a proapoptotic protein that is expressed by the damaged keratinocytes [6, 7] and is related to the cathepsin and trypsin-like families. Furthermore, SAP (serum amyloid $\mathrm{P}$ component), a member of the pentraxin family, has been identified both in diseased and normal skin, with evidence suggestive of its role in the development of LCA [10, 11]. Regarding this pathogenetic hypothesis, Hintner et al. [12], who analyzed the so-called keratin bodies, detected intermediate filament aggregates that were present at normal levels in healthy skin but increased in some disease conditions, such as LCA. Interestingly, along with keratins and the SAP component, they found a contemporary precipitation of immunoglobulin (Ig) molecules in the context of these deposits. This phenomenon can be interpreted as an attempt by the organism to remove this material through Ig-mediated opsonization and subsequent macrophage digestion, as already demonstrated in the literature [13, 14]. This finding is confirmed by the results of our proteomic analysis, with the presence of IgG and many complement fragments among those proteins identified by mass spectrometry along with the immunoreactivity of the skin biopsy to IgG. Other proteins found in our case, such as fibrinogen alpha chain, apolipoprotein A1, and gelsolin, have previously been de-

\section{KARGER}

(C) 2017 S. Karger AG, Base
E-Mail karger@karger.com

www.karger.com/spp
Fabio Pagni, MD

Department of Surgery and Translational Medicine

Pathology, University of Milano-Bicocca, via Cadore, 48 IT-20900 Monza (Italy)

E-Mail fabio.pagni@unimib.it 
Fig. 1. The 14-year-old patient presented peculiar skin lesions that were characterized by the alternation of hyper- and hypopigmented areas, along with a dermatological manifestation suggestive of GVHD during the differential diagnosis (a). For their complete assessment, a punch biopsy was performed, the histological examination of which revealed unspecific features such as hyperkeratosis, acanthosis, basal hyperpigmentation, and pigment incontinence (b). No leukocytic infiltrates, or other findings compatible with the diagnosis of GVHD, were evident. However, amorphous, glassy pink deposits were localized in the interface between the epidermis and papillary dermis, and the material showed a brick-red color and exhibited apple-green birefringence when stained with Congo red (c, d). These amyloid-like structures were negative to the AA protein IHC (not shown), but positively stained to CK-AE1/ AE3 with the same technique (e). Moreover, this material was accompanied by the deposition of IgG, but not C3 complement fragment, as demonstrated by immunofluorescence (f).

scribed as being responsible for systemic amyloidosis, but their role in the development of LCA is not yet known [15-19].

Finally, this patient differed from the presentation of LCA at an early age; moreover, we demonstrated the possible employment of a combined proteomic approach in order to identify the protein
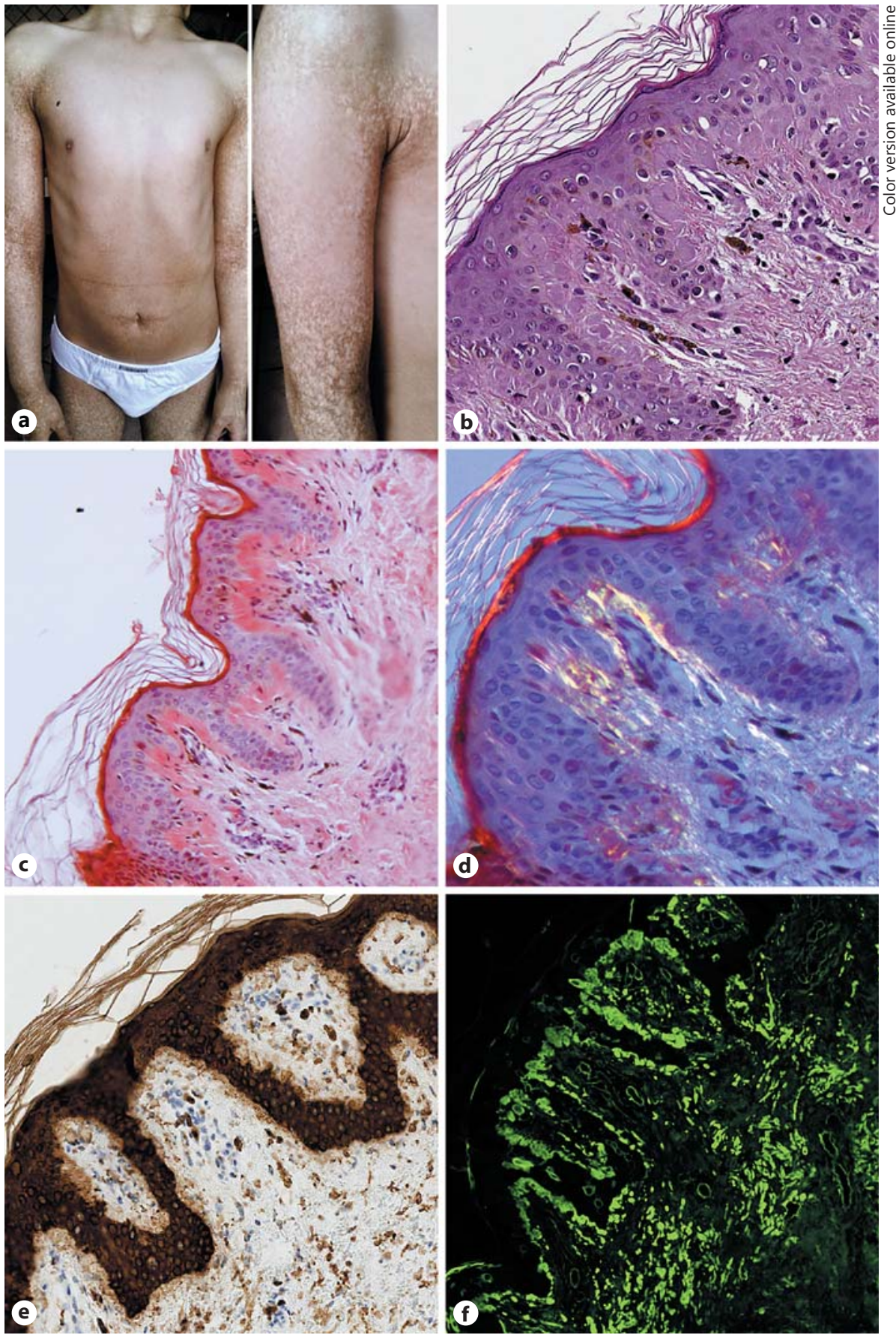

components of these deposits directly on FFPE tissue and, eventually, validate the identification through IHC tools. In the near future, the large-scale utilization of these research instruments could lead to a further improvement of our knowledge in this field and to a reclassification of the various forms of amyloidosis.

\section{Technical Notes}

Mass Spectrometric Analysis

Tissue was deparaffinized and the proteins were trypsinized following antigen retrieval [20]. Then, the generated tryptic peptides were analyzed by nLC-ESI-MS/MS [21]. The protein identification was assessed 
Table 1. List of proteins identified through nLC-ESI-MS/MS and grouped based on the role and localization in the organism

\begin{tabular}{|c|c|}
\hline Category & Identified proteins \\
\hline $\begin{array}{l}\text { Keratins and related } \\
\text { proteins }\end{array}$ & $\begin{array}{l}\text { keratin, type I cytoskeletal } 9,10,13,14,15,17,18,25, \mathrm{Ha} 1 \\
\text { keratin, type II cytoskeletal } 1,2,5,78 \\
\text { filaggrin }\end{array}$ \\
\hline $\begin{array}{l}\text { Immune system and } \\
\text { inflammation }\end{array}$ & $\begin{array}{l}\text { IgG- } 2 \text { chain } C \text { region, IgG- } 3 \text { chain } C \text { region, IgG- } 1 \text { chain } C \text { region, Ig kappa chain } C \text { region } \\
\text { C4b-binding protein alpha chain, complement } C 4-B \text {, complement } C 3 \text {, complement } \\
\text { component } C 9 \\
\text { annexin } A 1 \text {, cathepsin } G\end{array}$ \\
\hline Extracellular matrix & $\begin{array}{l}\text { collagen alpha-1 (I, III, VI, VII, XIV) chain } \\
\text { collagen alpha-2 (I, VI) chain } \\
\text { collagen alpha-3 (VI) chain } \\
\text { basement membrane-specific heparan sulfate proteoglycan core protein } \\
\text { fibronectin, fibrillin, lumican, tenascin-X, dermatopontin, prolargin, decorin, mimecan, } \\
\text { desmoplakin, biglycan, periostin }\end{array}$ \\
\hline Cytoskeleton & $\begin{array}{l}\text { vimentin, cytoplasmic actin, cofilin-1, gelsolin }{ }^{1} \text {, transgelin-2, tubulin alpha-1A chain, } \\
\text { F-actin-capping protein subunit beta } \\
\text { CEP295 N-terminal-like protein }\end{array}$ \\
\hline Nuclear proteins & $\begin{array}{l}\text { histone } \mathrm{H} 2 \mathrm{~A} . \mathrm{V} \text {, histone } \mathrm{H} 3.1 \mathrm{t} \text {, histone } \mathrm{H} 2 \mathrm{~B} \text { type } 1-\mathrm{C} / \mathrm{E} / \mathrm{F} / \mathrm{G} / \mathrm{I} \text {, histone } \mathrm{H} 2 \mathrm{~A} \text { type } 1-\mathrm{D} \text {, histone } \\
\mathrm{H} 2 \mathrm{~B} \text { type } 1-\mathrm{B} \text {, histone } \mathrm{H} 4 \text {, histone } \mathrm{H} 1.3 \\
\text { DNA-binding protein RFX5 } \\
\text { heterogeneous nuclear ribonucleoproteins A2/B1 }\end{array}$ \\
\hline Metabolism & $\begin{array}{l}\text { glyceraldehyde-3-phosphate dehydrogenase, alpha-enolase, pyruvate kinase PKM, L-lactate } \\
\text { dehydrogenase A chain, peroxiredoxin-6, adiponectin }\end{array}$ \\
\hline Serum proteins & $\begin{array}{l}\text { serum amyloid } \mathrm{P} \text {-component }{ }^{1} \text {, serotransferrin, hemoglobin subunit alpha and beta, fibrinogen } \\
\text { gamma chain, plasminogen, fibrinogen alpha chain }{ }^{1} \text {, vitronectin, annexin A5, fibulin, } \\
\text { hemopexin, protein AMBP } \\
\text { apolipoprotein } \mathrm{A}-\mathrm{IV} \text {, apolipoprotein } \mathrm{E}^{1} \text {, apolipoprotein } \mathrm{A}-\mathrm{I}^{1}\end{array}$ \\
\hline Proliferation and cell death & galectin- $7^{1}$, annexin A2, clusterin, homeobox protein ARX, protein S100 A4-6-11 \\
\hline $\begin{array}{l}\text { Differentiation and } \\
\text { senescence }\end{array}$ & $\begin{array}{l}\text { prelamin-A/C, 14-3-3 protein sigma, transforming growth factor-beta-induced protein ig-h3, } \\
\text { neuroblast differentiation-associated protein AHNAK, kinesin-like protein KIF2A, } \\
\text { calmodulin-like protein } 5\end{array}$ \\
\hline $\begin{array}{l}\text { Synthesis and degradation of } \\
\text { proteins }\end{array}$ & $\begin{array}{l}\text { heat shock protein beta-1, heat shock } 70 \mathrm{kDa} \text { protein } 1 \mathrm{~A} \text {, heat shock cognate } 71 \mathrm{kDa} \text { protein } \\
\text { tryptase alpha/beta-1, alpha-1-antichymotrypsin, lysozyme } \mathrm{C} \text {, alpha-1-antichymotrypsin } \\
60 \mathrm{~S} \text { ribosomal protein } \mathrm{L} 31 \text {, elongation factor } 1 \text {-alpha } 1,60 \mathrm{~S} \text { ribosomal protein } \mathrm{L} 31\end{array}$ \\
\hline
\end{tabular}

\footnotetext{
${ }^{1}$ Proteins previously reported to be present in the amorphous deposits of systemic or cutaneous amyloidosis.
}

by performing a database search using Mascot software (version 2.4.1), employing the built-in percolator algorithm $(p<0.05)$ and Swiss-Prot database (accessed May 2016; 551,193 sequences, $196,822,649$ residues).

\section{Acknowledgments}

This work was granted by the AIRC (Associazione Italiana per la Ricerca sul Cancro) fund MFAG2016 (ID 18445).

\section{References}

1 Partington MW, Marriott PJ, Prentice RS, Cavaglia A, Simpson NE: Familial cutaneous amyloidosis with systemic manifestations in males. Am J Med Genet 1981;10:65-75.

2 Pezzani L, Brena M, Callea M, Colombi M, Tadini G: X-linked reticulate pigmentary disorder with systemic manifestations: a new

\section{Disclosure Statement}

The authors declare that there is no conflict of interest regarding the publication of this paper. family and review of the literature. Am J Med Genet A 2013;161A:1414-1420.

3 Anderson RC, Zinn AR, Kim J, Carder KR: $\mathrm{X}$-linked reticulate pigmentary disorder with systemic manifestations: report of a third family and literature review. Pediatr Dermatol 2005;22:122-126. 
4 Fernandez-Guarino M, Torrelo A, Fernandez-Lorente M, Fraile G, García-Sagredo JM, Jaén P: X-linked reticulate pigmentary disorder: report of a new family. Eur J Dermatol 2008;18:102-103.

5 Kim BS, Seo S-H, Jung HD, Kwon K-S, Kim $\mathrm{M}-\mathrm{B}$ : X-linked reticulate pigmentary disorder in a female patient. Int J Dermatol 2010;49: 421-425.

6 Miura Y, Harumiya S, Ono K, Fujimoto E, Akiyama M, Fujii N, et al: Galectin-7 and actin are components of amyloid deposit of localized cutaneous amyloidosis. Exp Dermatol 2013;22:36-40

7 Ono K, Fujimoto E, Fujimoto N, Akiyama M, Satoh $\mathrm{T}$, Maeda $\mathrm{H}$, et al: In vitro amyloidogenic peptides of galectin-7: possible mechanism of amyloidogenesis of primary localized cutaneous amyloidosis. J Biol Chem 2014; 289:29195-29207.

8 Furumoto H, Shimizu T, Asagami C, Muto M, Takahashi M, Hoshii Y, et al: Apolipoprotein $\mathrm{E}$ is present in primary localized cutaneous amyloidosis. J Invest Dermatol 1998;111: 417-421.

9 Habermann MC, Montenegro MR: Primary cutaneous amyloidosis: clinical, laboratorial and histopathological study of 25 cases. Identification of gammaglobulins and C3 in the lesions by immunofluorescence. Dermatologica 1980;160:240-248.

10 Hintner H, Breathnach SM: Amyloid P components in normal human skin and skin with lesions (in German). Hautarzt 1988;39:712716.

11 Breathnach SM, Melrose SM, Bhogal B, de Beer FC, Black MM, Pepys MB: Immunohistochemical studies of amyloid $\mathrm{P}$ component distribution in normal human skin. J Invest Dermatol 1983;80:86-90.

12 Hintner H, Booker J, Ashworth J, Auböck J, Pepys MB, Breathnach SM: Amyloid P component binds to keratin bodies in human skin and to isolated keratin filament aggregates in vitro. J Invest Dermatol 1988;91:22-28.

13 Hintner H, Romani N, Stanzl U, Grubauer G, Fritsch P, Lawley TJ: Phagocytosis of keratin filament aggregates following opsonization with IgG-anti-keratin filament autoantibodies. J Invest Dermatol 1987;88:176-182.

14 Grubauer G, Romani N, Kofler H, Stanzl U, Fritsch P, Hintner H: Apoptotic keratin bodies as autoantigen causing the production of IgM-anti-keratin intermediate filament autoantibodies. J Invest Dermatol 1986;87:466471.

15 Asahina A, Yokoyama T, Ueda M, Ando Y, Ohshima N, Saito I, et al: Hereditary gelsolin amyloidosis: a new Japanese case with cutis laxa as a diagnostic clue. Acta Derm Venereol 2011;91:201-203.

16 Kiuru-Enari S, Haltia M: Hereditary gelsolin amyloidosis. Handb Clin Neurol 2013;115: 659-681.

17 Kiuru-Enari S, Keski-Oja J, Haltia M: Cutis laxa in hereditary gelsolin amyloidosis. Br J Dermatol 2005;152:250-257.

18 Sivalingam V, Patel BK: Familial mutations in fibrinogen $\mathrm{A} \alpha$ (FGA) chain identified in renal amyloidosis increase in vitro amyloidogenicity of FGA fragment. Biochimie 2016;127:4449.

19 Muscardin L, Cota C, Donati P, Sinagra JL, Paulli M, Merlini G, et al: Hereditary apolipoprotein A1 amyloidosis with cutaneous and cardiac involvement: a long familial history. Eur J Dermatol 2014;24:261-263.

20 De Sio G, Smith AJ, Galli M, Garancini M, Chinello C, Bono F, et al: A MALDI-Mass Spectrometry Imaging method applicable to different formalin-fixed paraffin-embedded human tissues. Mol Biosyst 2015;11:1507-1514.

21 Galli M, Pagni F, De Sio G, Smith A, Chinello C, Stella M, et al: Proteomic profiles of thyroid tumors by mass spectrometry-imaging on tissue microarrays. Biochim Biophys Acta DOI: 10.1016/j.bbapap.2016.11.020. 